\title{
DECISÃO JUDICIAL E ARGUMENTAÇÃO: LIMITES DA FUNDAMENTAÇÃO SOB UMA OBSERVAÇÃO SISTÊMICA ${ }^{1}$
}

\section{JUDICIAL DECISION AND ARGUMENTATION: LIMITATIONS OF THE REASONING UNDER A SYSTEMIC OBSERVATION}

Giselle Marie Krepsky Doutora em Direito pela UNISINOS/RS. Mestre em Educação. Professora do Programa de Mestrado em Direito da FURB. Líder do Grupo de Pesquisas CNPq/FURB: JUSTEC (Justiça, Educação e Ciência) e membro do Grupo de Pesquisas CNPq/FURB: Direitos Fundamentais, Cidadania e Justiça e Estado, Sociedade e Relações Jurídicas Contemporâneas. Coordenadora do Núcleo de Práticas Jurídicas da FURB. Blumenau, Santa Catarina, Brasil. ORCID http://orcid.org/0000-0003-0647-3602 E-mail: gkrepsky@furb.br.

Feliciano Alcides Dias Doutor em Direito pela Universidade do Vale do Rio dos Sinos - UNISINOS. Mestre em Direito. Professor do Programa de Mestrado em Direito da FURB. Líder do Grupo de Pesquisa CNPq/FURB: Estado, Sociedade e Relações Jurídicas Contemporâneas e membro dos Grupos de Pesquisa CNPq/FURB: Direitos Fundamentais, Cidadania \& Justiça e DTIn - Direito, Tecnologia e Inovação, além do Grupo de Pesquisa CNPq/UNOESC: Constitucionalismo Pós-Moderno, Hermenêutica e Processo: direitos humanos e novas tecnologias. Coordenador e Professor da Escola de Magistratura do Estado de Santa Catarina (ESMESC),

\footnotetext{
${ }^{1}$ Artigo recebido em 29/10/2020 e aprovado em 09/03/2021.
} 
extensão de Blumenau (FURB). Diretor do Centro de Ciências Jurídicas da FURB. Blumenau, Santa Catarina, Brasil.

ORCID: http://orcid.org/0000-0003-4936-9987 E-mail: feliciano@furb.br

Priscila Zeni de Sá

Doutora em Direito pela UNISINOS/RS. Mestre em Direito. Professora do Programa de Mestrado em Direito da FURB. Professora convidada da PUC-PR, Escola da Magistratura do Estado do Paraná (EMAP) e de Santa Catarina (ESMESC), e da Escola da Magistratura do Trabalho de Santa Catarina. Membro do Grupo de Pesquisas CNPQ/FURB: Constitucionalismo, Cooperação e Internacionalização CONSTINTER. Curitiba, Paraná, Brasil. ORCID: https://orcid.org/0000-0001-7498-6181 E-mail: priscilasa@ furb.br

RESUMO: Este artigo trata do dever de fundamentação das decisões judiciais e o papel da argumentação incrementado com o Código de Processo Civil brasileiro de 2015. A pesquisa foi desenvolvida considerando-se fundamento e argumento como método de controle constitucional das decisões. Sob a luz da teoria sistêmica de Niklas Luhmann e suas releituras contemporâneas o objetivo foi analisar a abertura e os limites do julgador ao decidir. Por meio do método indutivo e técnica bibliográfica, concluiu-se que o atual código impõe vinculação da decisão judicial ao caso concreto e exige fundamentação que indique de forma sofisticada tanto a repetição quanto a inovação do Direito por meio da argumentação jurídica. Apesar das limitações operacionais impostas ao Sistema do Direito voltadas para a segurança jurídica, há margem para construção da decisão judicial no exato limite da validade da fundamentação e da observância da garantia constitucional preconizada no artigo 93, IX da Constituição Federal. 
PALAVRAS-CHAVE: Decisão judicial; Argumentação; Fundamentação; Teoria Sistêmica;

ABSTRACT: This article deals with the duty to justify judicial decisions and the role of argumentation increased with the Brazilian Civil Procedure Code of 2015. The research was developed considering grounds and arguments as a method of constitutional control of decisions. In the light of Niklas Luhmann's systemic theory and his contemporary reinterpretations, the objective was to analyze the openness and limits of the judge when deciding. By means of the inductive method and bibliographic technique, it was concluded that the current code imposes binding of the judicial decision to the specific case and requires a reasoning that indicates in a sophisticated way both the repetition and the innovation of the Law through the legal argumentation. Despite the operational limitations imposed on the Law System aimed at legal certainty, there is scope for the construction of a judicial decision within the exact limit of the validity of the reasoning and observance of the constitutional guarantee provided for in Article 93, IX of the Federal Constitution.

KEYWORDS: Judicial decision; Argumentation; Reasoning; Systemic Theory.

\section{Introdução}

Do ponto de vista da teoria sistêmica, o Direito é um sistema encarregado de estabilizar as expectativas sociais a partir da aplicação do que é positivado pelo Sistema da Política (legislativo) e, sendo ele um dos que compõem o Sistema Social Global (sociedade), opera com base em códigos e programas. Os sistemas são autopoiéticos, ou seja, fechados do ponto de vista das suas operações, mas abertos cognitivamente porque observam os demais sistemas sociais como forma de evoluir e aprimorar suas estruturas.

Logo, a segurança jurídica pretendida pelo sistema do Direito e que pode ser confundida com apreço ao positivismo, não é senão uma garantia de que a apreciação das temáticas levadas ao sistema jurídico seja feita com base no seu código, ou seja, de acordo ou não com o Direito, e não conforme o poder, a economia ou outros interesses que não 
sejam de condão jurídico e que possam significar uma corrupção sistêmica, garantindo que haja uma certa previsibilidade nas decisões jurídicas, inclusive dos tribunais. ${ }^{2}$

Assim, por mais que o sistema possa optar por aprender e se adaptar ao meio, e isso inclui observar o que comunicam os demais sistemas (Ciência, Economia, Educação, Política, etc.), sempre haverá a garantia de que as decisões, ao fim e ao cabo, serão jurídicas e fundamentadas. Estas interrelações mostram que a própria positivação do Direito evidencia um nível de complexidade social ao qual a sociedade moderna alcançou e com o qual a Dogmática Jurídica tem que se adequar. ${ }^{3}$

Os Tribunais são organizações que compõem o centro duro do Sistema do Direito, e seus atores, os juízes, precisam cumprir os programas (leis, normas, etc.) que definem as orientações para suas decisões. Isto, entretanto, não quer dizer que as decisões possam ser obtidas por meio de uma dedução lógica, mesmo em se tratando de programas condicionais. Podem surgir conceitos indeterminados e outras situações de adequação social que requerem interpretação de acordo com a situação concreta.

Nesse contexto, o método subsuntivo deu lugar a um Judiciário protagonista e ativo, mas não se pode pressupor que o julgador tenha "carta branca" para julgar como entende de acordo com seus valores internos. A decisão judicial como modo de solucionar celeumas, relativizar vontades e impor deveres deve se dar no sistema de controle constitucional do dever de fundamentação previsto no texto constitucional. ${ }^{4}$ A fundamentação e a argumentação são, pois, o método de controle democrático das decisões em contraposição aos métodos antepassados quando o juiz era considerado a "boca-da-lei". 5

$\mathrm{O}$ ato de decidir sempre implica escolha, ainda que essa reflexão teórica pareça tautológica. E decidir implica produzir diferença que se distingue do conceito de ação proposto por Luhmann. ${ }^{6}$ Nesse sentido, as decisões são observações que são realizadas

\footnotetext{
${ }^{2}$ LUHMANN, Niklas. El derecho de la sociedad. Trad. Javier Tores Nafarrate, México: Iberoamericana, 2005. p. 253 (tradução nossa).

${ }^{3}$ LUHMANN, Niklas. Sociologia do Direito II. Rio de Janeiro: Tempo Brasileiro, 1985. p. 60.

${ }^{4}$ Cf. Art. 93, IX, CF/88.

5 MORAES, Maria Celina Bodin de. Do juiz boca-da-lei à lei boa-de-juiz: reflexões sobre a aplicaçãointerpretação do direito no início do século XXI. Revista de Direito Privado, São Paulo, v. 56, p. 11-30, 2013.

${ }^{6}$ LUHMANN, Niklas. Sistemas Sociales: Lineamentos para una teoría general. México: Anthropos, 1998. p. 269 e ss. (tradução nossa).
} 
mediante distinções que são chamadas de alternativas. Então, a decisão indica o lado que se prefere tomar das alternativas possíveis. É, portanto, operação autopoiética.

Essas operações ganham reestruturação a partir do Código de Processo Civil de 2015, em especial com a perspectiva do artigo 489. Por isso, a pesquisa descrita neste artigo, teve como foco de observação os limites e as possibilidades que advieram dos comandos processuais nele externados e a importância da argumentação sob a luz da teoria sistêmica de Niklas Luhmann e suas releituras contemporâneas. Para tanto, utilizou-se o método indutivo e a técnica bibliográfica.

\section{Decisão judicial e argumentação sob a perspectiva da Teoria dos Sistemas}

Sendo os procedimentos judiciais também uma diferenciação (como todos os sistemas), estabelecem limites em relação ao seu ambiente. Como salienta Luhmann, isso não quer dizer, entretanto, que os Tribunais estejam isolados nem do ponto de vista causal nem comunicativo. Eles não são prisões, mas correspondem ao centro duro do Sistema do Direito. Os Tribunais constroem para si mesmos um ambiente próprio intelectual para que o Sistema possa tomar decisões que sejam orientadas por regras internas pertinentes a sua estrutura a partir de uma filtragem das informações do ambiente. ${ }^{7}$ Dentro da perspectiva de autonomia do Sistema e de seus procedimentos, sabe-se que não há certeza quanto às decisões diante das múltiplas possibilidades com as quais o Sistema deverá estar apto a reduzir a complexidade. Essa tal autonomia igualmente se aplica aos processos judiciais e é aprimorada no âmbito das decisões com a crescente complexidade social. ${ }^{8}$

Se por um lado o Sistema do Direito precisa manter a sua estabilidade a partir da aplicação do seu código e programas, por outro, ele necessita de abertura necessária para que subsista e evolua. O princípio Luhmanniano de que o sistema é aberto (cognitivamente) porque é fechado (operacionalmente) e é fechado porque é aberto aplica-se também à obrigação de decidir dos Tribunais.

Nesse sentido, reafirma-se que a decisão é fechada posto que deve obedecer aos parâmetros referenciais operativos da estrutura a partir do código do sistema. Mas a decisão 
também é aberta na medida em que utiliza da argumentação e faz referência ao que é exterior ao Direito. ${ }^{9} \mathrm{O}$ caráter essencialmente fechado das decisões dá-se a partir dos argumentos formais com vistas à autorreferência do Sistema. Já o caráter aberto das decisões, que é o que particularmente interessou nesta pesquisa, dá-se com a argumentação substancial, ou seja, voltada para a heterorreferência. A primeira resguarda a possibilidade de que se chegue a uma decisão e que esta não se perca na complexidade que o mundo exterior oferece. A segunda visa impedir o total isolamento do Sistema nas suas referências internas ${ }^{10} \mathrm{e}$, portanto, viabiliza-se pela observação do entorno e suas contribuições para a evolução do Sistema por meio da abertura cognitiva. ${ }^{11}$

Então, a necessária validade conferida à decisão e os argumentos nela utilizados operam sob a forma de acoplamento estrutural e se manifestam sob a forma de textos jurídicos. É sob a forma de textos que o Sistema do Direito se coordena evitando que sejam fixadas com antecedência quais as operações que deverão ser utilizadas no caso concreto a fim de que se chegue a uma solução. Por esse motivo, os textos possuem acentuada relevância na argumentação jurídica, já que são capazes de estabelecer o enlace necessário entre argumento e validade para a decisão. Através deles, o sistema consegue atualizar os contextos internos, mas ao mesmo tempo, restringir possibilidades. Assim, encontrar os textos relevantes para cada decisão exige uma competência especializada que primeiro vem alicerçada no seu sentido literal e em sendo necessário e, posteriormente, na sua interpretação.

Por isso é que a interpretação pode ser considerada como uma verdadeira produção de novos textos [policontextos] que são baseados nos anteriores e mais antigos ampliando

\footnotetext{
${ }^{9}$ SIMIONI, Rafael Lazzarotto; PEREIRA, Henrique. A decisão jurídica em Niklas Luhmann: operação, diferença e abertura. In: CONPEDI, 18, São Paulo, 2009. Anais eletrônicos... Florianópolis: Fundação Boiteux, 2009, p. 2508.20 Disponível http://www.publicadireito.com.br/conpedi/manaus/arquivos/anais/sao_paulo/2261.pdf. Acesso em: 20 jun. 2020.

${ }^{10}$ LUHMANN, Niklas. El derecho de la sociedad. Trad. Javier Tores Nafarrate, México: Iberoamericana, 2005. p. 457-458.

${ }^{11}$ Para Niklas Luhmann "decisões e argumentos são funções, no interior do sistema jurídico, de duas formas de comunicações que são ao mesmo tempo separadas e mutualmente ligadas. Ambas comunicações contribuem, cada uma a seu modo, para a reprodução corrente de uma combinação de orientações normativas e cognitivas". Cf. LUHMANN, Niklas. A Restituição do Décimo Segundo Camelo: Do Sentido de uma Análise Sociológica do Direito. Trad. Dalmir Lopes Júnior. In: ARNAUD, André-Jean; LOPES JÚNIOR, Dalmir. Niklas Luhmann: Do Sistema Social à Sociologia Jurídica. Rio de Janeiro: Lumen Juris, 2004. p. 75.
} 
assim os fundamentos para novas decisões. ${ }^{12}$ No ato interpretativo novos textos e novos conceitos são construídos para o uso posterior em diferentes decisões. Logo, os textos não podem ser considerados conceitos, mas objetos dos quais podem originar-se conceitos ao serem interpretados. ${ }^{13}$ É neste processo que se caracteriza a Dogmática jurídica, eis que surge da necessidade de se argumentar mediante a construção e uso de conceitos. ${ }^{14}$

Quando o sentido literal é manifestamente insuficiente para a decisão, cabe à argumentação convincente encontrar alternativa entre várias que coadunem texto e decisão viável estruturalmente e justa. ${ }^{15}$ Argumentação esta que somente pode se dar no contexto de um observador de segunda ordem porque se trata de uma construção argumentativa voltada para outros observadores, voltada para a utilização dos textos na comunicação. ${ }^{16}$ De qualquer modo, há que se esclarecer que a comunicação que utiliza argumentos, como no caso da decisão jurídica, ocorre apenas para viabilizar efeitos no próprio sistema.

Assim, a argumentação jurídica é um meio pelo qual o Sistema do Direito se convence, refina e dá continuidade as suas próprias operações. ${ }^{17}$ Perceba-se que os argumentos são operações internas do Sistema do Direito, mas são operações de um tipo diferente. Eles aparecem tão somente quando o sistema é despertado para as diferenças de opinião na hora de atribuir o código legal/ilegal. ${ }^{18}$

Mas para isso deve-se compreender os conceitos de variação e redundância. No âmbito da decisão jurídica é necessário o equilíbrio entre variação e redundância. Os casos concretos que sempre exigirão uma tomada de decisão dos Tribunais são sempre diversos e como tais exigem que o Sistema leve tal diversidade em consideração. A argumentação transforma, pois, essa provocação em redundância operando em seu favor privilegiando a repetição, o respeito às semelhanças, para que se guardem informações e surpresas

${ }^{12}$ LUHMANN, Niklas. El derecho de la sociedad. Trad. Javier Tores Nafarrate, México: Iberoamericana, 2005. p. 402-403 (tradução nossa).

${ }^{13}$ LUHMANN, Niklas. El derecho de la sociedad. Trad. Javier Tores Nafarrate, México: Iberoamericana, 2005. p.449(tradução nossa).

${ }^{14}$ LUHMANN, Niklas. El derecho de la sociedad. Trad. Javier Tores Nafarrate, México: Iberoamericana, 2005. p. 451(tradução nossa).

${ }^{15}$ LUHMANN, Niklas. El derecho de la sociedad. Trad. Javier Tores Nafarrate, México: Iberoamericana, 2005. p.404(tradução nossa).

${ }^{16}$ LUHMANN, Niklas. El derecho de la sociedad. Trad. Javier Tores Nafarrate, México: Iberoamericana, 2005. p. 467 (tradução nossa).

${ }^{17}$ LUHMANN, Niklas. Legal Argumentation: An Analysis of its Form. In: Modern Law Review, London, v.58, n. 3, p.286, may 1995 (tradução nossa).

${ }^{18}$ LUHMANN, Niklas. Legal Argumentation: An Analysis of its Form. In: Modern Law Review, London, v.58, n. 3, p.287, may 1995 (tradução nossa). 
oferecidas pela complexidade exterior. É a preservação desta redundância que permite que haja uma reação frente às irritações e surpresas advindas do entorno. A variação então complementa a redundância de forma que o Sistema não caia numa eterna repetição habitual. ${ }^{19} \mathrm{E}$ tal processo ocorre "[...] dentro da rede histórica de decisões jurídicas precedentes, que são constituídas não só pela jurisprudência, mas também pela doutrina, pelas leis, pelos argumentos jurídicos[...]".20

Nesse sentido, o conceito de redundância evidencia que, quando se dispõe de um "lugar comum", um conceito ou uma observação que já se considera válida no sistema, podese contar com uma certa previsão de como a própria argumentação será desenvolvida no bojo da decisão, diminuindo a possibilidade de surpresas e mantendo uma certa estabilização. As surpresas oriundas da informação ou variação disponibilizada vão se reduzindo com o avanço dos argumentos a serem construídos. Então, tanto redundância quanto informação dizem respeito à operação de observação e se aplicam exatamente a sistemas que podem deixar que as surpresas apareçam e que, até mesmo procuram informação em havendo falta de complexidade interna. ${ }^{21}$

Muito embora o argumento sirva para manter a redundância do sistema e reforçar a sua estrutura atual, nada impede de que, na prática da distinção (distinguishing) e da superação (overruling), eventualmente e em pequenas doses, a irritação do meio possa permitir que o sistema incorpore a nova informação, sempre em movimentos não tão rápidos evitando assim a surpresa do sistema. É com esse processamento com base nas novas informações que ele pode identificar o estado em que se encontra e o estado para o qual está se dirigindo em sua evolução. ${ }^{22}$

Além disso, no centro encontra-se o princípio non liquet, a partir do qual as questões levadas aos Tribunais devem ser decididas obrigatoriamente, haja respaldo legislativo ou

\footnotetext{
${ }^{19}$ LUHMANN, Niklas. El derecho de la sociedad. Trad. Javier Tores Nafarrate, México: Iberoamericana, 2005. p. 438 (tradução nossa).

${ }^{20}$ SIMIONI, Rafael. Normatividade e Fundamentação material do Direito na Teoria dos Sistemas de Niklas Luhmann: O problema da normatividade implícita na dimensão construtivista da observação de segunda ordem. In: BARRETTO, Vicente de Paulo; DUARTE, Francisco Carlos; SCHWARTZ, Germano. Direito da Sociedade Policontextural. Curitiba: Appris, 2013. p. 318.

${ }^{21}$ LUHMANN, Niklas. A Restituição do Décimo Segundo Camelo: Do Sentido de uma Análise Sociológica do Direito. Trad. Dalmir Lopes Júnior. In: ARNAUD, André-Jean; LOPES JÚNIOR, Dalmir. Niklas Luhmann: Do Sistema Social à Sociologia Jurídica. Rio de Janeiro: Lumen Juris, 2004. p. 77-78.

${ }^{22}$ LUHMANN, Niklas. Legal Argumentation: An Analysis of its Form. In: Modern Law Review, London, v.58, n. 3, p.292, may 1995. (tradução nossa).
} 
não. Trata-se de uma dupla negação, pois a "não decisão não é permitida" e em última instância a coação legal para que se decida se resume na proibição de que o Tribunal se recuse a decidir. Apesar de que apenas parte (e provavelmente pequena) dos litígios sociais chega aos Tribunais, estes, na sua obrigação de decidir, atêm-se a aplicação do código e programas disponíveis no sistema jurídico.

Embora não se considere uma tarefa simples afirmar que além de aplicar a lei o Direito também cria direito, ao observar-se a obrigação que lhe é imposta pelo próprio sistema, percebe-se que, decidir é escolher entre várias alternativas. Isso não é apenas reconhecer direitos, mas, sobretudo, criar direitos e está diretamente ligado com a questão do tempo na decisão, porque a sentença (presente) sempre implica um passado e um futuro, mesmo que este seja ainda uma incógnita, ou incerteza. E o passado acaba por servir como uma ilusão de que haja um critério unívoco, certo e determinado para cada decisão. Mas serve, ressalte-se, como uma ilusão abstrata usada como recurso, porque se fosse assim, não haveria decisão justamente por não haver alternativas a serem escolhidas ou selecionadas.

Diante deste dilema, a teoria do Direito cria formas para que seja possível atuar sob a obrigação de decidir. E o instrumento mais comumente usado na prática para justificar decisões que são incomuns e mais complexas são as “desculpas” formais. Neste rol aparecem as nulidades processuais, prescrições, vícios, falta de regulamentação legal, entre outras formalidades que acabam por atenuar o sobrecarregamento do non liquet. Na prática, representa uma decisão legalmente aceita, mas com poucos argumentos. ${ }^{23}$ "Usa-se o direito como desculpa para a não aplicação do direito". ${ }^{24}$ Mas, ainda assim, são decisões. São, pois, escolhas, entre tantas outras que foram excluídas no ato de decidir.

\section{Fundamentação da decisão: limites e possibilidades a partir do artigo 489 do Código de Processo Civil brasileiro}

No que se refere ao papel da argumentação da decisão judicial, destaca-se que o Código de Processo Civil de 2015 dá enfoque especial a esta questão. Apenas do ponto de vista quantitativo, verifica-se que na codificação processual civil de 1973 não havia registro

\footnotetext{
${ }^{23}$ CAMPILONGO, Celso Fernandes. Política, sistema jurídico e decisão judicial. 2.ed. São Paulo: Saraiva, 2011. p.162-163.

${ }^{24}$ CAMPILONGO, Celso Fernandes. Política, sistema jurídico e decisão judicial. 2.ed. São Paulo: Saraiva, 2011. p.163.
} 
das categorias: "argumentação" ou "argumento" e havia apenas uma ocorrência da categoria "fundamentação". No vigente Diploma Processual, encontram-se três ocorrências de "argumentação" 25 , duas de "argumentos"26 e cinco de "fundamentação"27. Muito embora se saiba que o viés qualitativo, por si só, não demonstra uma significativa preocupação no que se refere a este tema, há uma indicação de que o ato decisório judicial se complexifica com estas inserções. ${ }^{28} \mathrm{E}$, como toda reorganização e reestruturação sistêmica, tem origem na tentativa de reduzir a complexidade social e a própria complexidade, mas que, paradoxalmente, torna outra vez a aumentá-la. Essa tentativa de redução de complexidade evidencia-se nas exatas palavras da Comissão Especial que elaborou o anteprojeto do CPC, sancionado através da Lei no ${ }^{\circ}$ 13.105, em 16 de março de 2015:

Com evidente redução da complexidade inerente ao processo de criação de um novo Código de Processo Civil, poder-se-ia dizer que os trabalhos da Comissão se orientaram precipuamente por cinco objetivos: 1) estabelecer expressa e implicitamente verdadeira sintonia fina com a Constituição Federal; 2) criar condições para que o juiz possa proferir decisão de forma mais rente à realidade fática subjacente à causa; 3) simplificar, resolvendo problemas e reduzindo a complexidade de subsistemas, como, por exemplo, o recursal; 4) dar todo o rendimento possível a cada processo em si mesmo considerado; e, 5) finalmente, sendo talvez este último objetivo parcialmente alcançado pela realização daqueles mencionados antes, imprimir maior grau de organicidade ao sistema, dando-lhe, assim, mais coesão. ${ }^{29}$

${ }^{25}$ Cf. artigos 303,436 e 1036 do CPC/2015.

${ }^{26} \mathrm{Cf}$. artigos 127 e 489 do CPC/2015.

${ }^{27} \mathrm{Cf}$. artigos 473, 927, 1.012, 1.013 e 1.026 do CPC/2015.

${ }^{28}$ Esta inclusão trata expressamente das decisões na esfera civil e nas áreas em que se aplica subsidiariamente o Código de Processo Civil brasileiro conforme preconiza o artigo 15: "Na ausência de normas que regulem processos eleitorais, trabalhistas ou administrativos, as disposições deste Código lhes serão aplicadas supletiva e subsidiariamente.”. Todavia, discute-se a aplicação subsidiária no Processo Penal e Tributário. A aplicação supletiva é mais que subsidiária, numa se está a suprir e noutra a auxiliar, motivo pelo qual, a aplicação do NCPC poder-se-ia dar também em questões de matéria penal. Cf. MEDINA, José Miguel Garcia. Novo Código de Processo Civil Comentado: com remissões e notas comparativas ao CPC/1973. 4.ed. rev. e ampl. São Paulo: Revista dos Tribunais, 2016. p. 82.

${ }^{29}$ BRASIL. Congresso Nacional. Senado Federal. Código de Processo Civil: anteprojeto, Brasília, DF, 2010.p.14. Disponível em: https://www.senado.gov.br/senado/novocpc/pdf/Anteprojeto.pdf. Acesso em: 20 jun. 2020 (grifo nosso). 
Revista Eletrônica de Direito Processual - REDP.

Rio de Janeiro. Ano 15. Volume 22. Número 2. Maio a Agosto de 2021

Periódico Quadrimestral da Pós-Graduação Stricto Sensu em Direito Processual da UERJ

Patrono: José Carlos Barbosa Moreira (in mem.). ISSN 1982-7636. pp. 239-267

www.redp.uerj.br

Trindade $^{30}$ aponta a nova lei como uma "revolução copernicana" no sistema processual brasileiro, pois a partir das novas regras incorporou-se uma teoria da decisão judicial democrática, que atingirá os ideais de coerência e integridade na jurisprudência brasileira. Para Nunes ${ }^{31} \mathrm{o}$ atual processo civil brasileiro baseia-se na absorção de um contraditório dinâmico, o que ele chama de processo constitucional democrático.

Além da manifesta intenção de sofisticar o Sistema do Direito e sua estrutura processual visando uma melhor operacionalização dos procedimentos, o Código de Processo Civil de 2015 pretende dar efetividade ao preceito constitucional do dever de fundamentar as decisões já previsto no artigo $93, \mathrm{IX},{ }^{32}$ da CF. Neste contexto, a fundamentação das decisões judiciais constitui, sobretudo, uma garantia do Estado Democrático de Direito Constitucional de que as pessoas não podem ser atingidas nos seus interesses por decisões que não demonstrem as suas razões, ou, em última instância, as razões do Estado para fazê1o. ${ }^{33}$ As razões são, pois, distinções que são introduzidas por um observador que, ao observar um texto proporciona por meio da interpretação um espaço livre para a argumentação. ${ }^{34}$

Em verdade, o próprio projeto de democracia constitucional observado na previsão acima e que deve possibilitar uma maior participação das respostas públicas, incluindo as decisões, faz romper com modelo tradicional de um processo que é individualista e tem na figura do julgador a primeira e última referência. Provoca-se assim uma abertura da

${ }^{30}$ TRINDADE, André Karam. Hermenêutica e jurisprudência: o controle das decisões judiciais e a revolução copernicana no Direito processual brasileiro. Revista de Estudos Constitucionais, Hermenêutica e Teoria do Direito (RECHTD), São Leopoldo, v. 7, n. 3, p. 243-252, set.- dez. 2015.

${ }^{31}$ Nesse sentido, "o processualismo constitucional democrático seria uma concepção teórica que busca a democratização processual civil mediante a problematização das concepções de liberalismo, socialização e pseudo-socialização processual (neoliberalismo processual), vistas em tensão, e da percepção do necessário resgate do papel constitucional do processo como estrutura de formação de decisões, ao partir do necessário aspecto comparticipativo e policêntrico das estruturas formadoras das decisões." Cf. NUNES, Dierle. Direito fundamental a um efetivo processo civil constitucionalizado. In: CLÈVE, Clèmerson Merlin. FREIRE, Alexandre. Direitos fundamentais e jurisdição constitucional: análise, crítica e contribuições. São Paulo: Revista dos Tribunais, 2014. p. 335-353.

${ }^{32} \mathrm{Cf}$. BRASIL. Emenda Constitucional $\mathbf{n}^{\mathbf{0}}$ 45, de 30 de dezembro de 2004. Disponível em: http://www.planalto.gov.br/ccivil_03/Constituicao/Emendas/Emc/emc45.htm. Acesso em: 20 jun. 2020.

${ }^{33}$ OLIVEIRA, Francisco Cardozo; KFOURI NETO, Miguel. O Alcance da Fundamentação da Decisão Judicial na Relação Entre Fatos e Normas segundo o Inciso I do $\S 1^{\circ}$ do Artigo 489 do Novo Código de Processo Civil. In: ALBERTO, Tiago Gagliano Pinto; VASCONCELLOS, Fernando Andreoni (Org.). O dever de Fundamentação no Novo CPC: Análises em torno do artigo 489. Rio de Janeiro: 2015.p. 211.

${ }^{34}$ LUHMANN, Niklas. El derecho de la sociedad. Trad. Javier Tores Nafarrate, México: Iberoamericana, 2005. p. 435 (tradução nossa). 
jurisdição para com a sociedade ao invés de um fechamento das estruturas do processo com a limitação de participação efetiva das partes ou pela conformação com a dogmática. ${ }^{35}$

Tal ato é agora prestigiado pela lei infraconstitucional a exemplo do que evidencia o artigo 489 do CPC/2015 e seu manejo deve se dar em consonância com a proposta constitucional introduzida em 1988 e reforçada em 2004. A observação pormenorizada desse artigo vislumbra identificar possíveis reflexos na abertura do Sistema do Direito ao decidir. Obrigado pela necessária fundamentação justificada, o julgador precisa sofisticar suas razões as quais certamente se encontrarão tanto na redundância quanto na variação do sistema do Direito.

Observa-se que a preocupação do legislador processualista foi trazer o julgador para o caso concreto, obrigando-o a analisar os fatos e fundamentos levantados pelas partes e não apenas reproduzir decisões padronizadas de casos análogos. A conduta do julgador deverá atender precipuamente a todos os argumentos das partes, numa conduta colaborativa ${ }^{36}$, observados, obviamente, o contraditório e a ampla defesa na qualidade de princípios constitucionais. O novel dever de fundamentação deve ser levado a sério, pois traz integridade e coerência à decisão judicial, ao mesmo tempo em que impede julgamentos subjetivos. ${ }^{37}$

Além disso, tal obrigação é corroborada pelo artigo 927, $\S 1^{\circ}$ do CPC que prevê que: "Os juízes e os tribunais observarão o disposto no art. 10 e no art. 489, § 1o, quando decidirem com fundamento neste artigo." e pelo artigo 371, pois, “O juiz apreciará a prova constante dos autos, independentemente do sujeito que a tiver promovido, e indicará na decisão as razões da formação de seu convencimento". Para tanto, o enfoque dar-se-á no artigo 489, § $1^{\circ}$, incisos de $\mathrm{I}$ a $\mathrm{VI}^{38}$ e, em especial no "como" poderá ocorrer a

\footnotetext{
${ }^{35}$ MORAIS, Jose Luis Bolzan de. Audiências públicas: novas práticas no Sistema de Justiça brasileiro e o princípio democrático (participativo). In: STRECK, Lenio Luiz; ROCHA, Leonel Severo; ENGELMANN, Wilson (Org.). Constituição, Sistemas Sociais e Hermenêutica. Anuário do Programa de Pós Graduação em Direito da UNISINOS. Porto Alegre, n.9, p. 177. 2012.

${ }^{36}$ Mitidiero alerta que não se trata de "colaboração entre as partes", mas sim uma colaboração do juiz com as partes e vice-versa. Cf. MITIDIERO, Daniel. A colaboração como modelo e como princípio no processo civil. Revista de Processo Comparado, São Paulo, v. 2, p. 83-97, jul.- dez. 2015.

${ }^{37}$ TRINDADE, André Karam. Hermenêutica e jurisprudência: o controle das decisões judiciais e a revolução copernicana no Direito processual brasileiro. Revista de Estudos Constitucionais, Hermenêutica e Teoria do Direito (RECHTD), São Leopoldo, v. 7, n. 3, p. 243-252, set.- dez. 2015.

${ }^{38}$ Apesar de que "a fundamentação da decisão judicial não consiste apenas no que consta do inc. II do referido artigo. Relatório e dispositivo também integram a fundamentação.” Cf. MEDINA, José Miguel Garcia. Novo Código de Processo Civil Comentado: com remissões e notas comparativas ao CPC/1973. 4.ed. rev. e ampl. São Paulo: Revista dos Tribunais, 2016. p. 773.
} 
fundamentação. Como alerta Luhmann, é claro que as razões devem ser fundamentadas já que existem boas e más razões. Sempre que se elege uma razão, está-se a excluir outra, pois decidir é sempre seleção de alternativas possíveis no Sistema. Portanto, há que se justificar a exclusão. ${ }^{39}$

Veja-se que o artigo 489 explicita o que não é aceitável como fundamento de decisão, mas não identifica diretamente o que pode ser enquadrado como decisão aceitável, deixando assim uma margem de construção de uma decisão que será uma entre as alternativas aceitáveis para o Sistema. Além disso, o dever de fundamentar ganha destaque quando o julgamento pretende ser diferente (da redundância já estabelecida), ou seja, cada vez que houver uma inovação, os argumentos deverão ser sobre valorados.

Todavia, o fato de que o diferente precise ser devidamente justificado, não retira o caráter decisório da decisão sob o ponto de vista sistêmico, pois até mesmo a decisão que apenas ratifica os precedentes confirmando o histórico de decisões ${ }^{40}$, e, portanto, reforçando a redundância, poderia tê-lo feito de forma diferente, mas escolheu não fazê-lo. Afinal, não decidir ou decidir da mesma forma, também é decidir. Assim, o paradoxo jurídico que se apresente sob a forma positivada "[...] pressupõe que as decisões se inserem nos argumentos e que toda a modificação do direito em vigor questiona argumentativamente também o direito não-modificado.”. ${ }^{41}$ Portanto, a argumentação para Luhmann é definida como “[...] a produção de argumentos e decisões; decisões estas, que por si próprias seriam mediadas por argumentos.". 42

Essa decisão então irá observar tanto fatos quanto direito. Mas também poderá observar outras exigências sejam elas de cunho ético, moral, a opinião pública, exigências econômicas, científicas, experiências jurisprudenciais do próprio tribunal, o direito comparado, [as diferentes correntes doutrinárias], e tudo que for necessário para a seleção

${ }^{39}$ LUHMANN, Niklas. El derecho de la sociedad. Trad. Javier Tores Nafarrate, México: Iberoamericana, 2005. p. 441 (tradução nossa).

${ }^{40}$ SIMIONI, Rafael Lazzarotto. O que a decisão observa? Contribuições da teoria dos sistemas de Niklas Luhmann às teorias pós-positivistas da decisão jurídica. In: SCHWARTZ, Germano (Org.). Juridicização das esferas sociais e fragmentação do direito na sociedade contemporânea. Porto Alegre: Livraria do Advogado, 2012. p. 89.

${ }^{41}$ LUHMANN, Niklas. A Restituição do Décimo Segundo Camelo: Do Sentido de uma Análise Sociológica do Direito. Trad. Dalmir Lopes Júnior. In: ARNAUD, André-Jean; LOPES JÚNIOR, Dalmir. Niklas Luhmann: Do Sistema Social à Sociologia Jurídica. Rio de Janeiro: Lumen Juris, 2004. p.76.

${ }^{42}$ LUHMANN, Niklas. A Restituição do Décimo Segundo Camelo: Do Sentido de uma Análise Sociológica do Direito. Trad. Dalmir Lopes Júnior. In: ARNAUD, André-Jean; LOPES JÚNIOR, Dalmir. Niklas Luhmann: Do Sistema Social à Sociologia Jurídica. Rio de Janeiro: Lumen Juris, 2004. p.76-77. 
Revista Eletrônica de Direito Processual - REDP.

Rio de Janeiro. Ano 15. Volume 22. Número 2. Maio a Agosto de 2021

Periódico Quadrimestral da Pós-Graduação Stricto Sensu em Direito Processual da UERJ

Patrono: José Carlos Barbosa Moreira (in mem.). ISSN 1982-7636. pp. 239-267

www.redp.uerj.br

de uma alternativa possível, ${ }^{43}$ sendo este "possível" a condição de possibilidade de conectar a justificativa com os elementos do Sistema do Direito e sem que haja qualquer espécie de corrupção sistêmica. Outras motivações da decisão tais como ideológicas, psicológicas ou flagrantemente solipsistas, não aparecem claramente no texto e por não interessarem ao Sistema do Direito, precisam ser absorvidas pela objetividade dos fundamentos. ${ }^{44}$

Tais regras impõem agora ao julgador limites no campo da decisão, mas são limites que deixam margem de abertura e construção teórico-prática. Este "como fazer", ou seja, como argumentar ${ }^{45}$ e justificar a razão da escolha, já não mais é exigência apenas de "[...] alguns eruditos catedráticos de laboratório que passeiam pelos corredores das Universidades [...]" ${ }^{46}$ Assim, se em outros contextos decisórios muitas vezes o que se vê é a total escassez de fundamentação da decisão com base em outras fontes que não a normativa, chegando até mesmo à proibição italiana de uso de citações acadêmicas, no Brasil é frequente o uso e até mesmo "abuso" de citações nas decisões apenas como argumento retórico. Porém, este cenário, ainda incerto quando ao seu futuro, mostra a possibilidade de que tais usos possam ganhar contornos de sofisticação argumentativa diante das imposições estabelecidas pelo artigo 489 do CPC. Vislumbra-se então, que o diálogo entre "acadêmicos e juízes" possa estreitar-se, que a produção acadêmico-científica poderá colocar-se como uma variação a ser observada pela Dogmática levando a uma ressonância externa que poderá se tornar necessária, caso não se encontrem construções conceituais na Dogmática atual.

${ }^{43}$ SIMIONI, Rafael Lazzarotto. O que a decisão observa? Contribuições da teoria dos sistemas de Niklas Luhmann às teorias pós-positivistas da decisão jurídica. In: SCHWARTZ, Germano (Org.). Juridicização das esferas sociais e fragmentação do direito na sociedade contemporânea. Porto Alegre: Livraria do Advogado, 2012. p. 89.

${ }^{44}$ WAMBIER, Teresa Arruda Alvim, et al. Primeiros Comentários ao Novo Código de Processo Civil: artigo por artigo. Lei no 13.105, de 16 de março de 2015. São Paulo: RT, 2015. p. 793-794.

45““...] a argumentação jurídica deve ser capaz de apresentar fundamentos normativos (implícitos que sejam) que lhe deem sustentação. $\mathrm{O}$ intérprete deve respeito às normas jurídicas - i.e, às deliberações majoritárias positivadas em um texto normativo -, à dogmática jurídica - i.e., aos conceitos e categorias compartilhados pela doutrina e pela jurisprudência, que, mesmo não sendo unívocos, têm sentidos mínimos - e deve absterse de voluntarismos. [...] a argumentação jurídica deve preservar a integridade do sistema. Isso significa que o intérprete deve ter compromisso com a unidade, com a continuidade e com a coerência da ordem jurídica.”. Cf. BARROSO, Luís Roberto. Curso de Direito Constitucional Contemporâneo. Os Conceitos Fundamentais e a Construção do Novo Modelo. 5.ed. São Paulo: Saraiva, 2015. p. 381-382.

${ }^{46}$ GRAJALES, Amós Arturo. El Artículo 489 de Nuevo Código Procesual Civil de Brasil y la Normativización del Nuevo Paradigma. In: ALBERTO, Tiago Gagliano Pinto; VASCONCELLOS, Fernando Andreoni (Org.). O dever de Fundamentação no Novo CPC: Análises em torno do artigo 489. Rio de Janeiro: 2015. p.71 (tradução nossa). 
Revista Eletrônica de Direito Processual - REDP.

Rio de Janeiro. Ano 15. Volume 22. Número 2. Maio a Agosto de 2021

Periódico Quadrimestral da Pós-Graduação Stricto Sensu em Direito Processual da UERJ

Patrono: José Carlos Barbosa Moreira (in mem.). ISSN 1982-7636. pp. 239-267

www.redp.uerj.br

Isso pode se tornar mais presente a partir de uma construção legislativa que tem utilizado conceitos indeterminados diante da necessidade de, cada vez mais, abarcar as complexidades sociais contemporâneas que já não comportam mais detalhamento e minúcias positivadas. As regras passam, em alguns casos, a ser menos detalhadas, mais flexíveis, abertas e apresentam eventualmente cláusulas gerais. ${ }^{47}$

Primeiramente, partindo do conceito jurídico indeterminado preceituado por Engisch $^{48}$ na doutrina alemã, em que se considera genericamente todos os conceitos jurídicos como indeterminados, pois todos os preceitos jurídicos demandam preenchimento com os dados da realidade, retorna-se à necessidade de vincular o caso concreto no processo de subsunção de todo e qualquer conceito jurídico. Utilizando o entendimento de que todo conceito jurídico é indeterminado e demanda um preenchimento, pode-se igualar "conceito jurídico" a "ato normativo".

Parece, então, que ao incluir a expressão "conceito jurídico indeterminado", o legislador tratou da categoria como gênero. ${ }^{49} \mathrm{O}$ conceito indeterminado contém expressão genérica que necessita de densificação pelo intérprete, mas a consequência já está prevista na regra. Diferente da cláusula geral, onde há a necessidade de duplo preenchimento: tanto

47 Não serão trabalhadas as diferenças entre cláusulas gerais e conceitos jurídicos indeterminados, uma vez que as regras aqui discutidas se aplicam a qualquer tipo de decisão que os contemplem. Nesse sentido, vale apenas lembrar que: “As leis contêm conceitos vagos e ocasionalmente trazem 'cláusulas gerais', que são expressões marcadamente carregadas de conteúdo axiológico, pois incorporam princípios. São sempre, intencionalmente, extremamente fluídas (vagas, indeterminadas) e seu conteúdo é construído paulatinamente [...]. Conceitos vagos ou indeterminados são aqueles que dizem respeito a objetos não muito bem definidos por eles mesmos. [...]". Cf. WAMBIER, Teresa Arruda Alvim, et al. Primeiros Comentários ao Novo Código de Processo Civil: artigo por artigo. Lei no 13.105 , de 16 de março de 2015. São Paulo: RT, 2015. p. 794. Além disso, "A cláusula geral, de forma especial e com maior evidência, permite que uma série de situações fáticas possa se submeter a um determinado tratamento jurídico a partir de um mesmo enunciado dogmático, sem que este esteja, desde logo, limitado em seu significado. Daí por que, em muitos casos, o enunciado normativo impõe, pela linguagem, na estrutura da própria cláusula geral, a utilização de conceitos indeterminados". Cf. CACHAPUZ, Maria Claudia Mércio. A construção de um conceito de privacidade, as cláusulas gerais e a concreção de direitos fundamentais. In: MARTINS-COSTA. Judith. Modelos de Direito Privado. São Paulo: Marcial Pons, 2014. p. 57. “A característica essencial das cláusulas gerais é o emprego de linguagem intencionalmente aberta e vaga, de modo a transferir para o intérprete o papel de completar o sentido da norma, à vista dos elementos do caso concreto. [...] Conceitos jurídicos indeterminados são expressões de sentido fluido, destinadas a lidar com situações nas quais o legislador não pôde ou não quis, no relato abstrato do enunciado normativo, especificar de forma detalhada suas hipóteses de incidência ou exaurir o comando a ser dele extraído." Cf. BARROSO, Luís Roberto. Curso de Direito Constitucional Contemporâneo. Os Conceitos Fundamentais e a Construção do Novo Modelo. 5.ed. São Paulo: Saraiva, 2015. p. 351-352.

48 ENGISCH, Karl. Introdução ao pensamento jurídico. Trad. J. Baptista Machado. Lisboa: Fundação Calouste Gulbenkian, 2014. p. 208.

${ }^{49}$ Nessa mesma linha é a posição de Tartuce. Cf. TARTUCE, Flavio. Impactos do novo CPC no Direito Civil. Rio de Janeiro: Forense, 2015. p. 20. 
da expressão constante da regra quanto da respectiva consequência. Ou seja, tanto as cláusulas gerais quanto os conceitos indeterminados necessitam do preenchimento por meio do julgador.

Assim, se o CPC pretendeu tratar do vocábulo "conceitos indeterminados" referindo-se às cláusulas gerais e conceitos indeterminados, incorreu em erro a lei processual, pois disse menos do que pretendia. Quis afirmar um gênero e acabou por abarcar apenas a espécie. Pretende-se aqui então fazer a interpretação do artigo 489, § 1º, II, no sentido de que não se considera fundamentada a decisão que empregar cláusulas gerais ou conceitos jurídicos indeterminados sem explicar o motivo concreto de sua incidência no caso.

Em especial, se tratando das cláusulas gerais, havendo a necessidade do preenchimento da hipótese legal e de sua consequência por se tratar de hipótese de vagueza socialmente típica, não significa que o juiz poderá atribuir o significado e a extensão de seu conteúdo ao seu livre arbítrio, pelo seu sentido de justiça ou ainda por "inescrutável julgamento de consciência" ${ }^{50}$ Pelo contrário, do julgador exige-se ainda mais empenho e dedicação para a fundamentação de suas decisões ${ }^{51}$ pois tem a obrigação de "averiguar os parâmetros em casos anteriores, em padrões de comportamento social objetivamente aferíveis, na praxe do setor, na prática eventualmente seguida pelas partes". ${ }^{52}$ Primando pela segurança jurídica, exige-se do intérprete "intensa atividade de argumentação" 53 , para de forma fundamentada e vinculada ao caso concreto vincular o texto normativo ao âmbito normativo.

Ou seja, não se trata de uma singularidade do caso, mas sim da concretização de uma norma de decisão que faça referência sempre ao caso concreto e à realidade em que está inserido, na circularidade entre direito e realidade.

Torna-se trabalho da doutrina e da academia jurídica construir o conteúdo destas regras. Logo, quanto maior for a indeterminação do conceito contido na norma, maior será

\footnotetext{
${ }^{50}$ MARTINS-COSTA, Judith. A boa-fé no direito privado: critérios para a sua aplicação. São Paulo: Marcial Pons, 2015. p. 145.

${ }^{51}$ MENKE, Fabiano. A interpretação das cláusulas gerais: a subsunção e concreção dos conceitos. Revista de Direito do Consumidor, São Paulo, v. 50, p. 9-35, abr. - jun. 2004.

${ }^{52}$ MARTINS-COSTA, Judith. A boa-fé no direito privado: critérios para a sua aplicação. São Paulo: Marcial Pons, 2015. p. 145.

${ }^{53}$ MIRAGEM, Bruno. Abuso de direito: ilicitude objetiva e limite ao exercício de prerrogativas no direito privado 2.ed. rev., atual. e ampl. São Paulo: Revista dos Tribunais, 2013. p. 183.
} 
Revista Eletrônica de Direito Processual - REDP.

Rio de Janeiro. Ano 15. Volume 22. Número 2. Maio a Agosto de 2021

Periódico Quadrimestral da Pós-Graduação Stricto Sensu em Direito Processual da UERJ

Patrono: José Carlos Barbosa Moreira (in mem.). ISSN 1982-7636. pp. 239-267

www.redp.uerj.br

o trabalho do julgador para justificar sua escolha. ${ }^{54}$ Neste contexto, torna-se mais difícil não associar a tarefa que se impõe ao julgador diante do artigo 489 com a ideia de um sistema mais aberto tanto aos princípios ${ }^{55}$ e os valores, já que as teorias de argumentação jurídica trazem consigo uma aceitação desta abertura. ${ }^{56}$

Especialmente na concreção das cláusulas gerais constata-se que há elementos extrassistemáticos ou intersistemáticos, sendo o juiz direcionado a valores existentes dentro ou fora do sistema ${ }^{57}$ e que "fundamentarão a decisão, motivo pelo qual esses fundamentos, uma vez reiterados no tempo, alcançarão uma relativa abstração que, por sua vez, viabilizará a ressistematização destes elementos originariamente inter e extrassistemáticos no interior do ordenamento jurídico". 58

Essas alterações no campo processual se justificam, sobretudo, porque no cenário brasileiro, muito se tem debatido acerca das decisões em todas as esferas. Diagnostica-se que os problemas se estendem em alguns vieses: ausência de padrão nas decisões, permitindo que casos similares sejam julgados com discrepância por vezes inimaginável; precariedade das fundamentações utilizadas; ausência de vinculação da decisão judicial com o caso concreto; além do mau uso das argumentações para a tomada de decisão.

Nesse tocante, destaca-se pesquisa realizada no Brasil que observou 692 Ações Diretas de Inconstitucionalidade; 35 Arguições de Descumprimento de Preceito Fundamental; 15 Ações Declaratórias de Constitucionalidade que tratavam das temáticas: segurança pública, reforma do judiciário e do processo e competição política totalizando 40

\footnotetext{
${ }^{54}$ WAMBIER, Teresa Arruda Alvim. Peculiaridades da fundamentação das decisões judiciais no Brasil - a nova regra nem é assim tão nova... In: RIBEIRO, Darci Guimarães; JOBIM, Marco Félix (Org.). Desvendando o Novo CPC. Porto Alegre: Do Advogado, 2015. p.161.

${ }^{55}$ Para fins deste item da pesquisa não serão aprofundados os conceitos e/ou diferenças entre princípios e regras, posto que o foco é a possibilidade de abertura da Dogmática para a construção decisória. Esclarece-se, todavia, que "Princípios e regras funcionam na prática argumentativa como normas jurídicas, mas são definidos conceitualmente de forma precisa pela dogmática jurídico-constitucional, entendida como instância do próprio sistema jurídico". Cf. NEVES, Marcelo. Entre Hidra e Hércules: Princípios e Regras Constitucionais. 2.ed. São Paulo: Martins Fontes, 2014. p. 119.

${ }^{56}$ GRAJALES, Amós Arturo. El Artículo 489 de Nuevo Código Procesual Civil de Brasil y la Normativización del Nuevo Paradigma. In: ALBERTO, Tiago Gagliano Pinto; VASCONCELLOS, Fernando Andreoni (Org.). O dever de Fundamentação no Novo CPC: Análises em torno do artigo 489. Rio de Janeiro: 2015. p.79 (tradução nossa).

${ }^{57}$ MENKE, Fabiano. A interpretação das cláusulas gerais: a subsunção e concreção dos conceitos. Revista de Direito do Consumidor, São Paulo, v. 50, p. 9-35, abr. - jun. 2004.

${ }^{58}$ MARTINS-COSTA, Judith. A boa-fé no direito privado: critérios para a sua aplicação. São Paulo: Marcial Pons, 2015. p. 157-8.
} 
acórdãos. ${ }^{59}$ Muito embora houvesse diferenças na observação qualitativa dependendo da temática, pode-se verificar que o Supremo Tribunal Federal (STF), "cita copiosamente variados doutrinadores" ${ }^{\prime 60}$. O que se ponderou na pesquisa foi que as fundamentações que se utilizaram de citações, muitas vezes trataram apenas de um recurso de autoridade para prestigiar a decisão que se tomou. A estrutura lógica passou a ser: se Y disse X; logo, decidese $X$. "[...] não se discute a validade de $X$. Em razão do prestígio de $Y$, ela será presumida. $\mathrm{O}$ argumento de autoridade não e, portanto, valido ou invalido, e sim aceito ou recusado."61 Dentre os argumentos de autoridade mais comuns encontrou-se:

a) Argumentos de autoridade fundados na doutrina: citações doutrinárias podem estar a serviço da compreensão do problema jurídico em questão ou se configurar como a citação de um autor famoso para fundar uma determinada decisão. Não é a citação feita para analisar ou contestar uma ideia, dialogando, dessa forma, com o autor citado. Trata-se, em vez disso, da citação que se faz para estabelecer pelo menos uma das premissas da asserção que se fará ao final da argumentação. b) Argumentos de autoridade fundados na jurisprudência: $\mathrm{O}$ que dissemos acima se aplica aqui. Citações jurisprudenciais podem ser usadas não para reconstituir a jurisprudência de uma corte e evidenciar sua ligação com o problema examinado. Numa argumentação de autoridade, não se lhes discutem os fundamentos ou a validade e não se demonstra a ligação com o caso concreto. $^{62}$

${ }^{59}$ RODRIGUEZ, José Rodrigo; NOBRE, Marcos (Coord.) Projeto Pensando o Direito. Série Pensando o Direito n ${ }^{\circ}$ 31/2010. Processo Legislativo e Controle de Constitucionalidade. Brasília: Ministério da Justiça, 2010.p.18. Disponível em: http://pensando.mj.gov.br/wpcontent/uploads/2015/07/31Pensando_Direito3.pdf. Acesso em: 20 jun. 2020.

${ }^{60}$ RODRIGUEZ, José Rodrigo; NOBRE, Marcos (Coord.) Projeto Pensando o Direito. Série Pensando o Direito $^{\circ}$ 31/2010. Processo Legislativo e Controle de Constitucionalidade. Brasília: Ministério da Justiça, 2010. p. 39-40.

${ }^{61}$ RODRIGUEZ, José Rodrigo; NOBRE, Marcos (Coord.) Projeto Pensando o Direito. Série Pensando o Direito ${ }^{\circ} 31 / 2010$. Processo Legislativo e Controle de Constitucionalidade. Brasília: Ministério da Justiça, 2010. p. 40 (sic).

${ }^{62}$ RODRIGUEZ, José Rodrigo; NOBRE, Marcos (Coord.) Projeto Pensando o Direito. Série Pensando o Direito $n^{\circ} 31 / 2010$. Processo Legislativo e Controle de Constitucionalidade. Brasília: Ministério da Justiça, 2010. p. 40. 
Todavia, a depender do conteúdo envolvido na decisão, houve também acórdãos com pouca citação da doutrina e jurisprudência e em outros se pode constatar muito mais argumentos externos ao Direito do que doutrina, jurisprudência ou princípios, evidenciando que não há mesmo um padrão decisório que torne a comunicação jurídica previsível. Além disso, em vários votos dos acórdãos as premissas maiores foram extraídas de obras de doutrinadores, artigos, livros, palestras, ou até mesmo apenas o nome de um autor, em que o conteúdo citado era menos relevante do que a própria autoridade citada. Não bastasse isso, identificou-se que as obras eleitas ainda variavam de acordo com a preferência de cada ministro e com o objeto de cada ação. ${ }^{63}$

Todas essas constatações denotam que, de fato, o "como" fundamentar e argumentar tem deixado a desejar diante do preceito constitucional e suas finalidades. Uma vez que as conexões ao caso concreto se mostram falhas ou inexistentes, que haja incongruências internas e que o uso da produção acadêmica muitas vezes se faça indiscriminadamente ou sem a sofisticação necessária, tais decisões perdem em qualidade e quiçá a sua validade.

A estrutura textual utilizada na argumentação por autoridade é sempre muito parecida: elabora-se uma tese, de saída, a partir de uma autoridade qualquer (legislação, doutrinador, caso julgado). Em seguida, são invocadas autoridades para corroborá-la, pouco importando a coerência entre elas, ou seja, a coerência entre as leis, casos julgados ou citações de doutrina utilizados. Por fim, é proposta uma solução para o caso como se ela fosse absolutamente óbvia, por ter sido, justamente, sustentada por praticamente 'todos', todas as autoridades relevantes sobre o assunto. Uma argumentação que é pura manipulação no sentido pejorativo da palavra, das fontes do direito. ${ }^{64}$

\footnotetext{
${ }^{63}$ RODRIGUEZ, José Rodrigo; NOBRE, Marcos (Coord.) Projeto Pensando o Direito. Série Pensando o Direito no 31/2010. Processo Legislativo e Controle de Constitucionalidade. Brasília: Ministério da Justiça, 2010.

${ }^{64}$ RODRIGUEZ, José Rodrigo. Como decidem as cortes? Para uma crítica do Direito (Brasileiro). Rio de Janeiro: FGV, 2013. p. 81.
} 
Revista Eletrônica de Direito Processual - REDP.

Rio de Janeiro. Ano 15. Volume 22. Número 2. Maio a Agosto de 2021

Periódico Quadrimestral da Pós-Graduação Stricto Sensu em Direito Processual da UERJ

Patrono: José Carlos Barbosa Moreira (in mem.). ISSN 1982-7636. pp. 239-267

www.redp.uerj.br

Ainda nos parágrafos $1^{\circ}$ e $2^{\circ}$ e seus incisos encontram-se termos que denotam a necessidade de que se faça uma explanação acerca da seleção eleita pelo julgador entre as alternativas possíveis no Sistema. § $1^{\circ}$, I - "explicar"; II - “explicar”; III- "justificar”; V"identificar"; VI- "demonstrar"; $\S 2^{\circ}$, "justificar". Apesar de haver entendimento de que "explicar" e os demais termos não levam a uma necessidade de detalhamento contundente como se fosse uma compreensão professoral e acadêmica, pois o "conceito" também não deve ser entendido de forma acadêmica, ${ }^{65}$ certo é que, para oferecer tais conexões entre o conceito e o caso, tal qual se exige no artigo, o julgador deverá demonstrar suficientemente o significado dos conceitos que utiliza. E para isso, em que pese nem toda situação concreta exigir, o julgador precisará explicitar argumentativamente sua escolha conceitual que extrapola a mera conexão com casos já decididos ou súmulas e precedentes. ${ }^{66}$

Ora, o inciso VI do $\S 1^{\circ}$ poderia, a primeira vista, denotar que bastaria o julgador reprisar na decisão enunciado de súmula, jurisprudência ou mesmo precedente ${ }^{67}$ que tenha sido trazido pela parte em havendo similaridade entre o caso julgado e o anterior, já que pela literalidade do inciso, só precisaria justificar caso deixasse de segui-los. Todavia, isto não

${ }^{65}$ ALBERTO, Tiago Gagliano Pinto; ALBERTO, Sabrina Santana Figueiredo Pinto. Conceitos Jurídicos Indeterminados e Fundamentação - Existirá o Céu dos Conceitos? In: ALBERTO, Tiago Gagliano Pinto; VASCONCELlOS, Fernando Andreoni (Org.). O dever de Fundamentação no Novo CPC: Análises em torno do artigo 489. Rio de Janeiro: 2015. p. 245-246.

66"Para mitigar a pluralidade de sentidos (possíveis) exige-se do jogador processual a indicação da teoria pela qual o significante é invocado. O problema reside que boa parte dos atores judiciais não faz a mínima noção de onde os conceitos são invocados. [...] O constrangimento democrático da efetiva fundamentação das decisões exige que o julgador e os jogadores (parte dos processos) sejam capazes de apontar o Conceito Operacional de cada um dos significantes. Dizer que a questão viola a dignidade da pessoa humana, por exemplo, deveria ser antecedida de uma questão: Em Kant ou Hegel? Não se trata de um ornamento exibido e teórico, porque sem o esclarecimento de qual base teórica o sentido pode advir, perdemo-nos em diálogos sem sentidos - lugar em que, portanto, vige o senso comum teórico dos juristas (Warat)." Cf. ROSA, Alexandre Morais da. É preciso fugir dos dribles retóricos da decisão judicial. In: Revista Consultor Jurídico, São Paulo, 09 set. 2016. Disponível em: http://www.conjur.com.br/2016-set-09/limite-penalpreciso-fugir-dribles-retoricos-decisao-judicial. Acesso em: 20 jun. 2020. Esse tal senso comum teórico dos juristas preconizado por Warat e abordado no segundo capítulo, chama a atenção para o uso dos conceitos. "O senso comum teórico não deixa de ser uma significação extra-conceitual no interior de um sistema de conceitos, uma ideologia no interior da Ciência, uma dóxa no interior da episteme.[...]. Em certo sentido, podemos dizer que, mediante o jogo estratégico dos conceitos, estes são reapropriados pelo senso comum dos juristas, convertidos, novamente, em significações, quer dizer, em signos, de múltiplas evocações conotativas." Cf. WARAT, Saber crítico e senso comum teórico dos juristas. In: Epistemologia e Ensino do Direito: O Sonho Acabou. Florianópolis: Fundação Boiteux, 2004. p. 30-31.

67 Importante ressaltar que "Precedente, assim, é diverso do conceito de jurisprudência, uma vez que precedentes não se tratam de várias decisões exemplificadas da opinião dos tribunais, mas de decisões racionalmente vinculantes, antes de tudo, para o próprio órgão que decidiu nos casos análogos futuros." Cf. ZANETI JR., Hermes. O Valor Vinculante dos Precedentes. Teoria dos Precedentes Normativos Formalmente Vinculantes. 2.ed. rev. e atual. Salvador: JusPODVIM, 2016. p. 299. 
está autorizado pelo inciso que o antecede, pois indica que, uma vez utilizando-se de precedente ou súmula ele precisa justificá-los estabelecendo o contato entre o preceito e o caso concreto. Portanto, os incisos V e VI dizem respeito ao mesmo tipo de explicação ou contextualização. Relembre-se: a decisão que apenas reforça a redundância, nesse sentido, deverá ser justificada tanto quanto a que absorve a informação para a decisão diferente.

Todas as decisões de modificação descontextualizadas não poderiam ser integradas dentro de uma construção normativa minuciosa [...], elas não poderiam ser compreendidas a partir do sistema jurídico, e por isso não ocorrem. (Isso entretanto é completamente independente da questão, se acaso o próprio sistema jurídico prevê as normas ou princípios não modificáveis, que são necessários para atender ou não todas as formas de modificação). O uso [...] da flexibilidade do direito positivo depende, em último caso, dessa segunda forma de comunicação que dispõe o sistema jurídico, quer dizer, da argumentação. ${ }^{68}$

Para a aplicação destes dispositivos legais, há que se observar em especial a questão dos precedentes. Se o caso a ser resolvido pode ser identificado com um precedente, ou seja, se a questão é semelhante ou igual, tal precedente não só pode como deve ser aplicado ao caso e deverá haver justificativa para tal posicionamento. Mas se houver questões que identifiquem diferenças entre o caso a ser decidido e o precedente, há que se justificar a distinção (distinguishing). Tal distinção terá, igualmente, que ser detalhadamente justificada. Veja-se que não só a distinção, mas a necessidade de superação do posicionamento jurisprudencial anterior servirá como justificativa para a não aplicação do precedente. Esta superação (overruling) ocorre, via de regra, por perderem a sua coerência tanto social quanto sistêmica de modo que a sua replicabilidade em novas situações deixa de ser autorizada. Há então que superar tal precedente. ${ }^{69}$

\footnotetext{
${ }^{68}$ LUHMANN, Niklas. A Restituição do Décimo Segundo Camelo: Do Sentido de uma Análise Sociológica do Direito. Trad. Dalmir Lopes Júnior. In: ARNAUD, André-Jean; LOPES JÚNIOR, Dalmir. Niklas Luhmann: Do Sistema Social à Sociologia Jurídica. Rio de Janeiro: Lumen Juris, 2004. p. 76.

${ }^{69}$ MITIDIERO, Daniel. Fundamentação e Precedente - Dois discursos a partir da decisão judicial. Revista de Processo, São Paulo, ano 37, v. 206, p.72-74, abr. 2012.
} 
Essa necessidade de justificativa para dar validade às decisões torna-se ainda mais contundente no inciso I, posto que não basta citar ou até mesmo parafrasear normativa existente, ou seja, é preciso novamente estabelecer o ponto de contato entre o caso concreto e fundamentação legal eleita, de sorte que o sentido do texto seja construído interpretativamente neste nexo causal. Ou seja, a auto-observação mais próxima do Direito que é direcionada ao conteúdo positivado não é suficiente para considerar válida a decisão. Mas como agora essa exigência se encontra positivada ingressa na própria estrutura do Direito a necessidade de se ampliar dita auto-observação, incitando uma sofisticação da Dogmática.

Da mesma forma, o inciso II exige tal conexão, mas trata de uma situação ainda mais complexa, pois entra na questão decisória o preenchimento de conceitos jurídicos indeterminados. Estes, por sua própria natureza, sempre exigiram um maior esforço argumentativo e, agora, aparecem como obrigação. Para tal desiderato, o julgador pode pautar-se em uma sequência de passos para a construção do sentido do Direito a fim de decidir o caso concreto. Estes passos elucidam a importância que, tanto a auto como a heterorreferência, têm:

a) Identificar se está diante de conceito e qual a sua significação; b) Identificar se se trata de um conceito jurídico, ou se demanda aporte teórico de outra área do conhecimento; c) Identificar se se trata de um conceito jurídico indeterminado; ou, ainda que determinado, de definição controvertida; d) Identificar qual a sua leitura do conceito jurídico indeterminado; ou determinado, porém controvertido; e) Identificar o ponto de contato entre conceito e o caso concreto. Uma vez que tenha estabelecido estas identificações, o juiz deverá: i) Aplicar o conceito, definindo-o sob a sua ótica e apoio doutrinário; ii) Definir o conceito jurídico e trazer aporte teórico oriundo do direito [auto-observação] ou de outra área do conhecimento [hetero-observação]; iii) Definir juridicamente o conceito jurídico indeterminado sob sua visão, ou 
explicitar a sua compreensão acerca do conceito que, embora determinado, revele controvérsias; [...] (grifo no original, grifo nosso). ${ }^{70}$

\section{Considerações Finais}

Com base na teoria sistêmica de Niklas Luhmann, esta pesquisa observou a importância da argumentação para a decisão judicial, especialmente porque o Código de Processo Civil de 2015 lhe conferiu um destaque privilegiado.

Ante o princípio non liquet, o Sistema do Direito tem a obrigação de decidir por meio de seu centro duro, os Tribunais. Ou seja, ele deve escolher uma entre tantas possibilidades e alternativas para emitir comunicação válida internamente com repercussão a todos os demais sistemas inerentes ao meio ambiente social. A decisão, nesse sentido, é aberta cognitivamente e fechada operacionalmente tal qual o sistema que a constrói e comunica.

Todavia, a fim de manter o equilíbrio entre a abertura (observação externa) e a clausura (observância de códigos e programas), o sistema do Direito precisa levar em consideração a variação e a redundância para a construção dos argumentos que suplantam a fundamentação das decisões. A argumentação é, pois, uma operação diferente e fundamental para a evolução do sistema, porquanto precisa manter a redundância das decisões conferindo segurança jurídica e reforçando a sua estrutura sem, contudo, deixar de permitir irritações externas vitais para a sua evolução.

Nesse contexto, o Código de Processo Civil vigente surge exatamente para auxiliar o papel do Direito de redução de complexidade do ambiente externo a ele, mas, com isso, acabou por aumentar sua complexidade interna, já que novos conceitos e interpretações são necessárias para concretizar a operação decisória. Essas inserções nos programas do Direito encontram-se alicerçadas no chamado processualismo constitucional democrático, a partir do qual reforça-se o imperativo descrito no artigo 93, IX da Constituição Federal, que garante o verdadeiro Estado Democrático do Direito Constitucional. Com tal imposição, não se

\footnotetext{
${ }^{70}$ ALBERTO, Tiago Gagliano Pinto; ALBERTO, Sabrina Santana Figueiredo Pinto. Conceitos Jurídicos Indeterminados e Fundamentação - Existirá o Céu dos Conceitos? In: ALBERTO, Tiago Gagliano Pinto; VASCONCELlOS, Fernando Andreoni (Org.). O dever de Fundamentação no Novo CPC: Análises em torno do artigo 489. Rio de Janeiro: 2015. p. 248-249 (grifo nosso).
} 
permite que os cidadãos sejam feridos em seus interesses sem a necessária demonstração da razão para tal. Essa razão, por sua vez, é construída pela interpretação e argumentação.

A valorização do argumento no Código de Processo Civil de 2015 não abre portas, entretanto, para a reconstrução textual e conceitual de forma ilimitada, mas apenas na juta medida de uma abertura jurisdicional compatível com um processo civil democrático. Se a obrigação da fundamentação justificada impõe ao julgador o dever de sofisticar suas razões, há que se sofisticar o ato de como fundamentar que vem explicitado no artigo 489, notadamente nos incisos I a VI.

Dentre eles, destaca-se a relevância dos conceitos jurídicos indeterminados, pois ao explicar-se os motivos do seu uso no caso concreto, estar-se-ia diante da possibilidade de construção argumentativa pelo julgador a fim de conferir a validade necessária da decisão por meio da adequada fundamentação. Apesar de parecer que o legislador incluiu a categoria "conceito jurídico indeterminado" como gênero no qual também estão inseridas as cláusulas gerais, fato é que, o trabalho argumentativo aumenta na medida em que tal uso não esteja devidamente justificado no caso concreto, o que pressupõe um construção interpretativa que, também deverá observar a redundância e a variação indispensáveis à segurança jurídica e à evolução do Sistema do Direito.

Ante o cenário decisório brasileiro apresentado na pesquisa, não causa estranheza o fato de o Código de Processo Civil inserir regras que balizam o dever de fundamentação. Veja-se que todos os incisos do $\S 1^{\circ}$ tratam de limitações na liberdade do julgador. Todavia, tais restrições podem ser observadas apenas como impedimento aos julgados que, por vezes arbitrários, praticam comutação constitucional o que levaria a uma alopoiese do Sistema Jurídico, ou, na melhor das hipóteses, uma heterorreferência total.

Fato é que, o caso concreto é que conduzirá a adequada construção argumentativa a fim de conferir validade ao fundamento utilizado e que toda escolha argumentativa representa uma entre as possíveis e internamente válidas no sistema. Isso, tanto para decidir igual ou diferente ao passado. Precisa justificar tanto a repetição quanto a inovação ou distinção.

Isso porque o Sistema do Direito precisa prever também um regramento para o seu desenvolvimento, ou seja, precisa prever técnicas de superação ou evolução. Essa superação poderá se dar pela transformação (transformation) ou pela sua reescrita (overriding). Essa 
superação, todavia, não pode se tornar uma surpresa nem tampouco dar tratamento não isonômico para as partes que, em momentos diferentes, pleiteiam demandas idênticas.

Logo, conclui-se que a decisão constrói-se tanto a partir da auto-observação (incluídas a jurisprudência, precedentes, enunciados e até mesmo a teoria ou doutrina do Direito) quanto da abertura para a hetero-observação (pareceres técnicos de outras áreas, produção acadêmico-científica sobre o Direito e de outras fontes do conhecimento interdisciplinaridade). Ambas orientam a comunicação jurídica que o Sistema precisa fazer a partir do caso concreto. É por isso que, apesar das exigências de fundamentação do CPC não serem absolutamente inovadoras, proporcionam de um lado limitações ao poder discricionário da decisão judicial, mas, por outro, podem fomentar uma abertura do Sistema do Direito (sua Dogmática). A adequada condução deste equilíbrio deverá, pois, estar ancorada na sofisticação exigida da fundamentação.

\section{REFERÊNCIAS}

ALBERTO, Tiago Gagliano Pinto; ALBERTO, Sabrina Santana Figueiredo Pinto. Conceitos Jurídicos Indeterminados e Fundamentação - Existirá o Céu dos Conceitos? In: ALBERTO, Tiago Gagliano Pinto; VASCONCELLOS, Fernando Andreoni (Org.). O dever de Fundamentação no Novo CPC: Análises em torno do artigo 489. Rio de Janeiro: 2015. p. 245-246.

BARROSO, Luís Roberto. Curso de Direito Constitucional Contemporâneo. Os Conceitos Fundamentais e a Construção do Novo Modelo. 5.ed. São Paulo: Saraiva, 2015.

BRASIL. Constituição da República Federativa do Brasil, de 5 de outubro de 1988.

Disponível em:

\section{http://www.planalto.gov.br/ccivil_03/constituicao/constituicaocompilado.htm.}

Acesso em: 20 jun. 2020.

BRASIL. Emenda Constitucional $n^{\circ} 45$, de 30 de dezembro de 2004. Disponível em: http://www.planalto.gov.br/ccivil_03/Constituicao/Emendas/Emc/emc45.htm. Acesso em: 20 jun. 2020.

BRASIL. Congresso Nacional. Senado Federal. Código de Processo Civil: anteprojeto,
Brasília,
$\mathrm{DF}$, 2010.p.14.
Disponível
em: 
https://www.senado.gov.br/senado/novocpc/pdf/Anteprojeto.pdf. Acesso em: 20 jun. 2020

BRASIL. Lei nº 13.105, de 16 de março de 2015. Código de Processo Civil. Disponível em: http://www.planalto.gov.br/ccivil_03/_ato2015-2018/2015/lei/113105.htm. Acesso em: 20 jun. 2020.

CACHAPUZ, Maria Claudia Mércio. A construção de um conceito de privacidade, as cláusulas gerais e a concreção de direitos fundamentais. In: MARTINS-COSTA. Judith. Modelos de Direito Privado. São Paulo: Marcial Pons, 2014.

CAMPILONGO, Celso Fernandes. Política, sistema jurídico e decisão judicial. 2.ed. São Paulo: Saraiva, 2011.

ENGISCH, Karl. Introdução ao pensamento jurídico. Trad. J. Baptista Machado. Lisboa: Fundação Calouste Gulbenkian, 2014.

GRAJALES, Amós Arturo. El Artículo 489 de Nuevo Código Procesual Civil de Brasil y la Normativización del Nuevo Paradigma. In: ALBERTO, Tiago Gagliano Pinto; VASCONCELLOS, Fernando Andreoni (Org.). O dever de Fundamentação no Novo CPC: Análises em torno do artigo 489. Rio de Janeiro: 2015.

LUHMANN, Niklas. Legitimação pelo procedimento. Brasília: Universidade de Brasília, 1980.

LUHMANN, Niklas. Sociologia do Direito II. Rio de Janeiro: Tempo Brasileiro, 1985.

LUHMANN, Niklas. Legal Argumentation: An Analysis of its Form. In: Modern Law Review, London, v.58, n. 3, p.286, may, 1995.

LUHMANN, Niklas. Sistemas Sociales: Lineamentos para una teoría general. México: Anthropos, 1998.

LUHMANN, Niklas. A Restituição do Décimo Segundo Camelo: Do Sentido de uma Análise Sociológica do Direito. Trad. Dalmir Lopes Júnior. In: ARNAUD, AndréJean; LOPES JÚNIOR, Dalmir. Niklas Luhmann: Do Sistema Social à Sociologia Jurídica. Rio de Janeiro: Lumen Juris, 2004.

LUHMANN, Niklas. El derecho de la sociedad. Trad. Javier Tores Nafarrate, México: Iberoamericana, 2005.

MARTINS-COSTA, Judith. A boa-fé no direito privado: critérios para a sua aplicação. São Paulo: Marcial Pons, 2015. 
MEDINA, José Miguel Garcia. Novo Código de Processo Civil Comentado: com remissões e notas comparativas ao CPC/1973. 4.ed. rev. e ampl. São Paulo: Revista dos Tribunais, 2016.

MENKE, Fabiano. A interpretação das cláusulas gerais: a subsunção e concreção dos conceitos. Revista de Direito do Consumidor, São Paulo, v. 50, p. 9-35, abr. - jun. 2004.

MIRAGEM, Bruno. Abuso de direito: ilicitude objetiva e limite ao exercício de prerrogativas no direito privado 2.ed. rev., atual. e ampl. São Paulo: Revista dos Tribunais, 2013.

MITIDIERO, Daniel. A colaboração como modelo e como princípio no processo civil. Revista de Processo Comparado, São Paulo, v. 2, p. 83-97. jul.- dez., 2015.

MORAES, Maria Celina Bodin de. Do juiz boca-da-lei à lei boa-de-juiz: reflexões sobre a aplicação-interpretação do direito no início do século XXI. Revista de Direito Privado, São Paulo, v. 56, p. 11-30, 2013.

MORAIS, Jose Luis Bolzan de. Audiências públicas: novas práticas no Sistema de Justiça brasileiro e o princípio democrático (participativo). In: STRECK, Lenio Luiz; ROCHA, Leonel Severo; ENGELMANN, Wilson (Org.). Constituição, Sistemas Sociais e Hermenêutica. Anuário do Programa de Pós Graduação em Direito da UNISINOS. Porto Alegre, n.9, 2012. p. 161-188.

NEVES, Marcelo. Entre Hidra e Hércules: Princípios e Regras Constitucionais. 2.ed. São Paulo: Martins Fontes, 2014.

NUNES, Dierle. Direito fundamental a um efetivo processo civil constitucionalizado. In: CLÈVE, Clèmerson Merlin. FREIRE, Alexandre. Direitos fundamentais e jurisdição constitucional: análise, crítica e contribuições. São Paulo: Revista dos Tribunais, 2014. p. 335-353.

OLIVEIRA, Francisco Cardozo; KFOURI NETO, Miguel. O Alcance da Fundamentação da Decisão Judicial na Relação Entre Fatos e Normas segundo o Inciso I do $§ 1^{\circ}$ do Artigo 489 do Novo Código de Processo Civil. In: ALBERTO, Tiago Gagliano Pinto; VASCONCELLOS, Fernando Andreoni (Org.). O dever de Fundamentação no Novo CPC: Análises em torno do artigo 489. Rio de Janeiro: 2015. 
RODRIGUEZ, José Rodrigo; NOBRE, Marcos (Coord.) Projeto Pensando o Direito. Série Pensando o Direito $\mathrm{n}^{\mathrm{o}}$ 31/2010. Processo Legislativo e Controle de Constitucionalidade. Brasília: Ministério da Justiça, 2010.p.18. Disponível em: http://pensando.mj.gov.br/wp-content/uploads/2015/07/31Pensando_Direito3.pdf.

Acesso em: 20 jun. 2020.

ROSA, Alexandre Morais da. É preciso fugir dos dribles retóricos da decisão judicial. In:

Revista Consultor Jurídico, São Paulo, 09 set. 2016. Disponível em: http://www.conjur.com.br/2016-set-09/limite-penal-preciso-fugir-dribles-retoricosdecisao-judicial. Acesso em: 20 jun. 2020.

SIMIONI, Rafael Lazzarotto; PEREIRA, Henrique. A decisão jurídica em Niklas Luhmann: operação, diferença e abertura. In: CONPEDI, 18., São Paulo, 2009. Anais eletrônicos... Florianópolis: Fundação Boiteux, 2009, p. 2508. Disponível em: http://www.publicadireito.com.br/conpedi/manaus/arquivos/anais/sao_paulo/2261.pd f. Acesso em: 20 jun. 2020.

SIMIONI, Rafael Lazzarotto. O que a decisão observa? Contribuições da teoria dos sistemas de Niklas Luhmann às teorias pós-positivistas da decisão jurídica. In: SCHWARTZ, Germano (Org.). Juridicização das esferas sociais e fragmentação do direito na sociedade contemporânea. Porto Alegre: Livraria do Advogado, 2012. p. 85-107.

SIMIONI, Rafael. Normatividade e Fundamentação material do Direito na Teoria dos Sistemas de Niklas Luhmann: O problema da normatividade implícita na dimensão construtivista da observação de segunda ordem. In: BARRETTO, Vicente de Paulo; DUARTE, Francisco Carlos; SCHWARTZ, Germano. Direito da Sociedade Policontextural. Curitiba: Appris, 2013.

TARTUCE, Flavio. Impactos do novo CPC no Direito Civil. Rio de Janeiro: Forense, 2015. TRINDADE, André Karam. Hermenêutica e jurisprudência: o controle das decisões judiciais e a revolução copernicana no Direito processual brasileiro. Revista de Estudos Constitucionais, Hermenêutica e Teoria do Direito (RECHTD), São Leopoldo, v. 7, n. 3, p. 243-252, set.- dez. 2015.

WAMBIER, Teresa Arruda Alvim, et al. Primeiros Comentários ao Novo Código de Processo Civil: artigo por artigo. Lei n ${ }^{\circ} 13.105$, de 16 de março de 2015. São Paulo: RT, 2015. p. 793-794. 
Revista Eletrônica de Direito Processual - REDP.

Rio de Janeiro. Ano 15. Volume 22. Número 2. Maio a Agosto de 2021

Periódico Quadrimestral da Pós-Graduação Stricto Sensu em Direito Processual da UERJ

Patrono: José Carlos Barbosa Moreira (in mem.). ISSN 1982-7636. pp. 239-267 www.redp.uerj.br

WAMBIER, Teresa Arruda Alvim. Peculiaridades da fundamentação das decisões judiciais no Brasil - a nova regra nem é assim tão nova... In: RIBEIRO, Darci Guimarães; JOBIM, Marco Félix (Org.). Desvendando o Novo CPC. Porto Alegre: Do Advogado, 2015.

WARAT, Saber crítico e senso comum teórico dos juristas. In: Epistemologia e Ensino do Direito: O Sonho Acabou. Florianópolis: Fundação Boiteux, 2004.

ZANETI JR., Hermes. O Valor Vinculante dos Precedentes. Teoria dos Precedentes Normativos Formalmente Vinculantes. 2.ed. rev. e atual. Salvador: JusPODVIM, 2016. 